\title{
Reflections on Strengthening Ideological and Political Education in Colleges and Universities in the Era of Integrating Media Integration
}

\author{
Dandan Zhang ${ }^{1}$ \\ ${ }^{1}$ Taizhou College, Nanjing Normal University, Taizhou, China \\ Correspondence: Dandan Zhang, Taizhou College, Nanjing Normal University, Taizhou, Jiangsu, China. E-mail: \\ 51431118@qq.com
}

Received: November 20, 2021

Accepted: December 18, 2021

Online Published: December 23, 2021

doi:10.20849/aes.v6i2.971

URL: https://doi.org/10.20849/aes.v6i2.971

Subject name: Innovative Research on Ideological and political education in Colleges and universities from the perspective of media integration level: special ideological and political project of philosophy and Social Sciences in Colleges and universities of Jiangsu Province (2020) project approval No.: 2020sjb1254.

\begin{abstract}
With the continuous maturation of China's social network information technology, the arrival of the media era has greatly changed the environment of Ideological and political education in Colleges and universities, and increased the difficulty of education. In order to improve the effect of ideological education, colleges and universities take the initiative to explore new working methods of Ideological and political education, so as to promote the all-round development of students.
\end{abstract}

Keywords: financial media era, Ideological education in colleges and universities, reflection

\section{Introduction}

as China enters the era of financial media, the dissemination of information is more convenient and fast, and the information content is more and more rich. College students have strong ability to accept new things. While obtaining their own information with the help of financial media, they will also be affected by relevant information. Therefore, colleges and universities should strengthen ideological and political education to set up correct values for students.

\section{Strengthening the Construction of Ideological and Political Teachers}

In the era of integrating media, the difficulty of Ideological and political education in Colleges and universities is gradually increasing, and the ideological and political work is mainly undertaken by relevant teachers. The construction of teachers directly determines the effect of Ideological and political education in Colleges and universities. Therefore, colleges and universities should take the initiative to strengthen the construction of ideological teachers. Ideological and political teachers in Colleges and universities are the leaders of students' ideological and political education. Only with solid theoretical knowledge of ideological and political education , can they not be affected by adverse factors in the era of integrating media and always strengthen the values of the Party and socialism, thus laying the foundation for the development of ideological and political education in the later stage. At the same time, with the advent of the era of integrated media, college students can obtain various ideas in the society with the help of various media, so as to enrich and comprehensive their own ideas. However, in these ideological contents, there are both excellent and advanced ideas and some dregs, which will inevitably affect college students in the process of acceptance, This is not conducive to the healthy development of their own body and mind. Ideological and political teachers in Colleges and universities should recognize the confusion of college students in the era of integrating media, actively strengthen the study of Ideological and political contents such as Marxism Leninism, party history, party and government, strengthen their political position, clarify social values, actively use relevant theoretical knowledge of Ideological and political education, guide college students to actively dredge their own confusion and help students understand the essence of confusion, and make them actively solve problems under the leadership of Ideological and political teachers, so as to promote students' physical and mental development. At the same time, in the era of integrated media, the circulation speed and production speed of social information are accelerating, and the society and various 
industries are changing rapidly. In education, ideological and political teachers must adapt to the changes of the times and social development, and take the initiative to innovate educational work, so as to make the effect of Ideological and political education more remarkable. In addition, ideological and political education teachers should recognize the importance of practice, take the initiative to research and explore the financial media, and introduce it into Ideological and political education, so as to realize the innovation of Ideological and political education. In specific practice, colleges and universities organize relevant teachers to carry out ideological and political learning. While strengthening the research of Ideological and political content, they guide teachers to take the initiative to learn the new media platform and related applications, so as to improve the ability of Ideological and political teachers to apply ideological and political science and media related to technologies (Tian, S. Z., 2020).

\section{Actively Build an Ideological and Political Education Platform}

In the era of integrated media, while college students change their way of life and learning under the influence of social thoughts, new changes have taken place in the development of Ideological and political education in Colleges and universities. Many ideological and political educators recognize the irreversibility of the development of the times and actively integrate into the era of integrated media. While studying new media, they start from the direction of Ideological and political education and increase the forms of education with the help of the application of new media related technologies, so as to promote the smooth development of Ideological and political education. In the process of integrating new media and traditional media in Colleges and universities, colleges and universities should also actively absorb media resources from the society, flexibly use the content of Ideological and political education, and connect it with the study and life of college students, so as to achieve the goal of rich content and diverse forms of ideological and political education. This change of Ideological and political education in Colleges and universities can greatly stimulate students' interest, improve students' enthusiasm for education, and finally improve the effect of Ideological and political education.

In carrying out ideological and political education in the era of integrated media, colleges and universities should take the initiative to build the media platform of Ideological and political education from many aspects in combination with the characteristics and related technologies of the era of integrated media. With the development of network information technology in China, related technologies are becoming more and more mature, and have played a great advantage in education and teaching. In Ideological and political education, colleges and universities should actively introduce network information technology and build a network ideological and political education system, so as to break the classroom restrictions of traditional ideological and political education in Colleges and universities with the help of the advantages of network technology, make the ideological and political education richer in content and more diverse in forms, and students can receive ideological and political education anytime and anywhere. At the same time, colleges and universities can also supervise the campus with the help of the media. Specifically, in the supervision, we can optimize the media of university content with the help of network information related technologies and rules, by integrating the characteristics and development trend of media, and relying on relevant laws and regulations, so as to build a safe and healthy network and media environment for students, so as to lay a foundation for the later ideological and political education environment. In addition, in the construction of Ideological and political education platform with the help of new media and traditional media, colleges and universities should understand their respective advantages, and give full play to their respective values with the help of the guidance of Ideological and Political Education (Liu, Y., \& Huang, C. P., 2020).

In the construction of specific ideological and political education platform, colleges and universities should guide teachers related to ideological and political education to actively transmit the theoretical knowledge, practical activities and other contents of Ideological and political education to the platform. Colleges and universities should classify relevant contents in combination with specific ideological and political education contents and students' grades, so as to facilitate students' learning in combination with their own needs, so as to fully mobilize students' autonomy in learning ideological and political education. In the ideological and political education platform, colleges and universities should promote the ideological and political content and related courses loved by students on the home page, and take the initiative to upload the ideological and political course content popular with students offline, so as to avoid conflicts between students and other learning. At the same time, colleges and universities should give full play to their resource advantages, make good use of the ideological and political education platform, actively invite well-known ideological and political scholars to teach on the platform, enrich students' learning methods and stimulate students' autonomy. In the operation of the ideological and political education platform, colleges and universities should actively collect and analyze the relevant information and data in the ideological and political education platform, and analyze the students' 
Ideological and political education needs and interests with the help of broadcast volume and other relevant indicators, so as to help optimize the form and content of the ideological and political education platform with colleges and universities, so as to provide students with a better ideological and political learning environment.

\section{Attach Importance to the Integration of Ideological and Political Education and Media Integration}

With the development of China's social economy and the continuous acceleration of knowledge renewal, students are affected by the acceleration of social rhythm in their study and life. In the acquisition of information, they usually browse and absorb the more interested graphic content and short videos with the help of fragmented time, which makes students occupy most of their spare time by these information. In order to improve the effect of Ideological and political education in the era of integrated media, colleges and universities must analyze the psychology and behavior habits of current college students, highlight the status of students, actively combine the needs and behavior characteristics of students, and effectively improve the quality of Ideological and political education with the help of the integration of Ideological and political education and integrated media (Zhang, C. W., 2021).

After combining the characteristics and behavior of students, colleges and universities explore relevant educational work with the integration of Ideological and political education and financial media. In specific practice, universities should take the initiative to broadcast the news, newspapers, Internet platforms, trill and other hot topics in the society, so that students can pay attention and discuss the related contents in the university media, so that students can think and learn in the ideological and political atmosphere of universities, and deepen their understanding of the content of Ideological and political education. At the same time, colleges and universities should grasp the interactive characteristics of new media. While ensuring that students interact with surrounding teachers and students after receiving information, they can also promote students to communicate and discuss with information publishers and relevant personnel, so that colleges and universities can better understand students' ideological state and facilitate colleges and Universities to take reasonable ideological and political education measures. In Ideological and political education, colleges and universities should fully recognize the advantages of new media and take the initiative to guide students to explore relevant contents with the help of various forms. Colleges and universities can also use relevant ideological and political education platforms to enable students to associate the contents of Ideological and political education with society and current events in the interaction of the platform, so as to deepen students' understanding and understanding of Ideological and political education, With the infiltration of media education in Colleges and universities, students are gradually baptized and infected by ideological and political education. In gradually accepting ideological and political education, students have formed their own values and social cognition, and the effect of Ideological and political education in Colleges and universities has been greatly improved. Therefore, colleges and universities should strengthen the integration of Ideological and political education and financial media, and actively carry out relevant innovative education exploration.

\section{Conclusion}

In a word, the financial media age is the information age. College students' thoughts will be adversely affected when they are exposed to a large amount of social information. While carrying out professional education, colleges and universities should also pay attention to students' ideological development, actively carry out exploration related to ideological and political education, and make use of the advantages of the media era to promote the development of Ideological and political education in Colleges and universities.

\section{References}

Liu, Y., \& Huang, C. P. (2020). On the innovation of Ideological and political education in Colleges and universities in the era of integrating media. Reporter Observation, 506(30), 91-92.

Tian, S. Z. (2020). Innovative thinking on the teaching methods of Ideological and political courses in Colleges and universities in the era of integrating media. Shanxi Youth, 584(12), 179-179.

Zhang, C. W. (2021). On the innovation of Ideological and political education in Colleges and universities in the era of integrating media. Journal of Jiamusi Vocational College, 37(1), 2.

\section{Copyrights}

Copyright for this article is retained by the author(s), with first publication rights granted to the journal.

This is an open-access article distributed under the terms and conditions of the Creative Commons Attribution

license (http://creativecommons.org/licenses/by/4.0/). 